\title{
Knowledge Matters: Policy Cross-Pressures and Black Partisanship
}

\section{Citation}

Gay, Claudine. 2014. Knowledge Matters: Policy Cross-Pressures and Black Partisanship.

Political Behavior 36, no. 1: 99-124.

\section{Published Version}

doi:10.1007/s11109-013-9227-3

\section{Permanent link}

http://nrs.harvard.edu/urn-3:HUL.InstRepos:12336378

\section{Terms of Use}

This article was downloaded from Harvard University's DASH repository, and is made available under the terms and conditions applicable to Open Access Policy Articles, as set forth at http:// nrs.harvard.edu/urn-3:HUL.InstRepos:dash.current.terms-of-use\#OAP

\section{Share Your Story}

The Harvard community has made this article openly available.

Please share how this access benefits you. Submit a story.

Accessibility 


\title{
Knowledge Matters: \\ Policy Cross-Pressures and Black Partisanship
}

\author{
Claudine Gay \\ Department of Government \\ Harvard University \\ 1737 Cambridge St. \\ Cambridge, MA. 02138 \\ cgay@gov.harvard.edu \\ 617-496-5470 (Office) \\ 617-495-0438 (Fax)
}

\begin{abstract}
Black Americans are a core Democratic constituency, despite holding views on social issues that put them in conflict with the party. Conventional wisdom attributes this partisan commitment to the salience of race and concerns about racial inequality. This paper considers whether the Democratic bias derives in part from low levels of political knowledge. Using data from the 2004 National Annenberg Election Study, this paper examines how political knowledge moderates the relationship between social issue cross-pressures and partisan attitudes among Black Americans. I demonstrate that the extent to which Democratic allegiance persists despite policy disagreements depends on whether blacks are sufficiently knowledgeable to act on their policy views, and not simply on the importance that blacks assign to their racial commitments. It is only among politically knowledgeable Black Americans that social issue crosspressures are at all politically consequential; for them, Democratic partisanship is resilient but not immune to policy disagreements. For blacks with low levels of political knowledge, partisan support is unaffected by policy disagreements. This pattern is most pronounced among religiously active Black Evangelicals, for whom social issues are highly salient.
\end{abstract}

Keywords: Black Americans, race, party, political knowledge, social issues 


\section{Introduction}

Black Americans are a core Democratic constituency. As a group, they overwhelmingly identify as Democrats, with many describing themselves as strong partisans. They consistently support Democratic candidates, at rates (e.g. $88 \%$ for John Kerry, $95 \%$ for Barack Obama) unrivaled by other Democratic segments of the population (e.g. women, working class, Latinos), and at all levels of government. This pattern has been unbroken for well over 40 years, since the Democratic and Republican parties polarized on the issue of race in the mid- to late- 1960s. The conventional wisdom attributes this Democratic bias to the salience of racial issues and concerns about racial inequality among Black Americans, and to a widely shared conviction that as individuals they benefit from efforts to advance the interests of Blacks as a group.

As central as racial group interests are in Black Americans' thinking about politics, however, they are not the only concerns. Black Americans care, sometimes a great deal, about other issues. On some of these issues, their views are at odds with their commitments to the Democratic Party. Witness, for example, Black mobilization in support of Proposition 8, a 2008 state ballot initiative that amended the California Constitution to prohibit samesex marriage. Yet, despite the dissonance, and to the consternation of the Republican Party, Blacks remain overwhelmingly Democratic, in their self-identification, their vote choice, and their affect toward partisan objects. It is possible that racial concerns are so dominant as to render other issues politically inconsequential, at least with respect to partisan support. That, in a nutshell, is the standard claim. But what I ask in this paper is whether part of what sustains these Democratic commitments is simple ignorance. Is it possible that Black Americans, no more informed about politics than other citizens, do not know the extent to which their policy views put them in conflict with their party or how to reconcile their views with their partisan choice? Is it possible that low political knowledge, and not only the bonds of race, helps to sustain Black Americans' Democratic commitments?

The goal of this paper is to identify the role of political information in Black partisanship. 
Specifically, what I will examine is how political knowledge conditions the relationship between social issue cross-pressures and African American's partisan attitudes, including their party identification, vote choice, and evaluations of political leaders. The analysis reveals that the strength of Democratic allegiance, in the face of policy disagreement, depends on whether Blacks are sufficiently knowledgeable to act on their policy views - not simply on the importance that Blacks assign to their racial commitments. Black Americans whose policy views put them at odds with the Democratic Party are less Democratic than Black Americans in-line with the party, but only if they are highly politically informed.

\section{Right Policy, Left Party and the Role of Political Information}

Political observers have long recognized the socially conservative tendencies of the Black mass public. In stark contrast to their views on racial and social welfare policy, African Americans are firmly anchored to the political right of whites (and other minorities) on a range of moral and cultural issues, including abortion, gay rights, and women's role in society (Tate 2010; Hajnal and Lee 2011; Kinder 2001). ${ }^{1}$ In recent elections, Republican candidates have sought to capitalize on this conservative strain - for example, by highlighting so-called 'pro-family' themes and support for faith-based initiatives - as part of their courtship of minority voters, in the hopes of weakening the Democratic Party's hold on the Black constituency (Smith 2005).

Yet, even as social issues have emerged as a polarizing force (at least among partisans) in American politics (Abramowitz 2010), Republicans have largely failed to convert Black social conservatism into greater support for their candidates or agenda. Blacks remain reliably Democratic, despite opinions seemingly favorable to Republican policy initiativesan intransigence that Frymer (1999) and others have argued contributes to the group's 'electoral capture.' Insofar as 'race remains the central factor in Black partisan decision

\footnotetext{
${ }^{1}$ Tate (2010) argues that Blacks are becoming more conservative on social welfare issues. But, on balance, they remain liberal, when viewed relative to whites and relative to their opinions on social and cultural issues.
} 
making,' as Hajnal and Lee $(2011,143)$ conclude, the limited receptivity to the Republican party is unsurprising. Just as civil rights were critical in wooing the the last Black Roosevelt Republicans to the Democratic Party in the 1960s (Tate 2010), persistent concerns about racial inequality undercut support for a party whose social conservatism stands alongside racial policy positions that are viewed as anathema to Black interests. ${ }^{2}$

Black Americans may stand out as a particularly striking example of weak policy-party linkage, but they are not unique. Two generations of scholarship have repeatedly affirmed Converse (1964)'s early insight: '. . for the public, in sharp contrast to the elite, party preference seems by and large to be set off in a belief system of its own, relatively unconnected to issue positions' $(1964,229)$. Converse reached this conclusion when comparing the 'fragmented and chaotic' political belief systems of a cross-section of the national electorate to the 'constraint and organization' of an elite sample of 1958 Congressional candidates (Converse 1964, 228-231). Even within the national electorate itself, however, contemporary scholars have uncovered considerable variation in the degree to which policy views align with partisan preferences, with political knowledge emerging as an important moderator (Althaus 2003; Bartels 1996; Claassen and Highton 2009; Delli Carpini and Keeter 1996; Gilens and Murakawa 2002; Kam 2005). Members of the mass public differ in the amount of political information they have, whether that is knowledge about the nature of partisan cleavages (Gilens and Murakawa 2002; Kam 2005; Lauderdale 2010), about the roles and responsibilities of prominent public figures or branches of government (Althaus 2003; Delli Carpini and Keeter 1996), about policy-relevant facts (Gilens 2001), or about public affairs in general (Bartels 1996). The quality and quantity of political information one holds, together with how that information is organized, are attributes associated with a wide variety of behavioral differences - from the style (and outcome) of political decision-making to the susceptibility to campaign influences, stability of attitudes, and levels of political participation

\footnotetext{
${ }^{2}$ Although FDR secured more than two-thirds of the Black vote in his election bids, the majority of African Americans continued to self-identify as Republicans (Hajnal and Lee 2011). As late as 1960, nearly a quarter of Black respondents to the American National Election Study described themselves as Republican.
} 
(Galston 2001; Sniderman, Brody and Tetlock 1993; Zaller 1992). Put simply, the politically knowledgeable are different from the rest of the electorate. Among those differences is that individuals who are more informed about politics are more likely to exhibit issue profiles that are consistent with their partisanship (Claassen and Highton 2009; Lauderdale 2010). For the most informed citizens, opposing policy views are mirrored in opposing partisan preferences. In fact, Lauderdale (2010) finds that individuals who are 'fully informed' about partisan cleavages sort themselves across parties by policy opinion as thoroughly as members of the Senate. By comparison, for those who are uninformed about partisan cleavages, there is little evidence of sorting behavior; issue positions and partisan profiles do not overlap. To wit, knowledge is critical in the policy-party link.

Most of what we know about the consequences of low political knowledge comes from the study of white public opinion (but see Bartels (1996); Kuklinski and Hurley (1994)). Moreover, the insights that have emerged from this vast literature, by and large, have not been integrated into the research on black partisanship. But African Americans, too, are differentially exposed to political information, making it quite likely that the 'thesis of universally low mean sophistication' applies to them as well (Luskin 1987, 886). Additionally, information inequalities among the black mass public may be particularly large with respect to information about partisan cleavages on non-racial policies. To the extent that Blacks draw much of their political information from 'bibles, barbershops, and BET' (Harris-Lacewell 2004), and have more limited contact with mainstream political and social institutions, the information they receive is skewed heavily toward a racially oriented analysis of politics and public affairs (Dawson 1994). Not only is this analysis likely to differentiate between Democratic and Republican advocacy on racial issues, but it likely spends more time doing that then highlighting partisan cleavages on topics such as abortion, gay rights, or school prayer. When Black Democratic legislators appear on Tavis Smiley, for example, it is not to discuss Democratic efforts to repeal the Defense of Marriage Act. ${ }^{3}$ Whereas awareness

\footnotetext{
${ }^{3}$ A notable exception to the lack of direct Black leadership on social issues is Julian Bond's 2009 speech at the National Equality Rally in which he equated homophobia to racism and declared that "no people of
} 
of Republican opposition to minority set-asides is widespread (Zaller 1986), many Blacks may not know that congressional Republicans favor a constitutional amendment to ban gay marriage. ${ }^{4}$ Black Americans may be less likely to possess the knowledge necessary to link social policy and party, because they are less likely to be exposed to it. With social and cultural issues treated as 'secondary to an agenda focused on Black civil rights and social welfare' (Tate 2010, 98), Black Americans may hear (and absorb) relatively few elite political arguments on these topics. In short, channels of political communication within the black mass public foster a shared understanding of the political implications of blacks' racial commitments, even while obscuring the potential relevance of other values and considerations. Forty years of research on political knowledge suggest that such information asymmetries probably contribute to the weak link, among blacks, between opinion on social issues and partisan attitudes.

Where Black Americans may deviate from the patterns revealed by the study of white public opinion is in the extent to which information moderates the policy-party link. Research in black politics demonstrates clearly that racial group concerns are highly salient in black political decision-making; such concerns are likely to constrain, if not necessarily negate, information effects for blacks to a degree that they do not for white Americans. Even among the most well-informed blacks, unlike the most well-informed white Americans, (conservative) social issue positions may be only modestly related to (pro-Republican) partisan attitudes. Blacks' Democratic allegiance is probably more resilient than prior research on political information might predict. Rather than partisan defection, for blacks, political information may contribute to an attenuation in positive partisan affect. ${ }^{5}$

Thus, the intuition that motivates this paper draws together insights from two literagood will should oppose marriage equality.'

${ }^{4}$ Zaller (1986) finds that 'blacks, although tending to score lower than whites on other information scales, score higher on race information' $(1986,6)$.

${ }^{5}$ Hajnal and Lee (2011) document a growing propensity among Blacks to reject partisan labels altogether and self-identify as Independents. This rejection, they argue, is motivated not by views on moral and social issues but by perceptions of waning Democratic advocacy on racial issues. Notably, their analysis of relationship between partisan identification and social issues, such as gay rights, does not take political information into account. 
tures that rarely intersect - research on political knowledge that is often silent on race and, consequently, may overstate the role of information for blacks; research on black partisanship that is often silent on political information and, consequently, may overstate the role of race. Taken together, these literatures predict that, given more information about partisan cleavages on social issues, African Americans with conservative policy views should evaluate the Democratic party and political actors less favorably, and the Republican party more favorably, than African Americans with liberal policy views. In the absence of political information, the generally positive orientation toward the Democrats and negative orientation toward the Republicans should be shared by socially liberal and socially conservative African Americans alike. Furthermore, the alignment of policy and partisan views should be more sensitive to levels of political information for whites than it is for blacks.

\section{Data and Methods}

The data I use for this paper come from the 2004 National Annenberg Election Study. I draw specifically on the national rolling cross-section, consisting of daily surveys conducted from October 7,2003-November 16,2004. These data are valuable as they include a very large sub-sample of Black respondents $(\mathrm{N}=6550)$. For analysis that relies on segmenting the Black population along several dimensions - policy views, levels of information - a large sample of respondents is critical.

The 2004 NAES includes a number of indicators that measure partisan attitudes, policy views, and political knowledge. In addition to a seven-point party identification measure (Party ID: 1 'Strong Republican' to 7 'Strong Democrat') and indicators of presidential vote intention (Bush Vote) and job approval (Bush Job: 1 'Approve' and 0 'Disapprove'), I construct a dependent variable from the respondents' evaluations of the Democratic (John Kerry) and Republican (George Bush) presidential nominees along several dimensions: overall favorability; cares about people like you; inspiring; leadership; trust; shares your values; knowledgeable. On each dimension, respondents scored the party nominees on an 11-point 
scale, ranging from 0 (unfavorable opinion) to 10 (favorable opinion). I calculated the average of the scores to measure the respondent's general affect toward each candidate. I use the difference between the average Bush and Kerry scores to assess relative favorability (Bush-Kerry Favorability: -10 Pro-Kerry to +10 Pro-Bush). ${ }^{6}$

The policy domain where Black opinion is most at odds with the Democratic Party concerns social issues such as abortion, gay rights and women's role in society. Perhaps not surprisingly, given high levels of Black religiosity, many Black Americans hold conservative social views. To measure opinion on social issues, I leverage a range of survey items, beginning with direct measures of policy support for abortion rights (Abortion), same-sex marriage (Gay Marriage), and school vouchers (Vouchers). More than a quarter of Black NAES respondents favor a total ban on abortion; nearly 40 percent favor a constitutional amendment banning same-sex marriage; and 55\% support federal provision of vouchers 'to help parents send their children to private schools.' In addition to these three direct policy items, I also draw on items that measure respondents' more general orientation toward socially progressive politics. As a broad indicator of views regarding women's role in society, I use the favorability of 'feminist organizations' (Favor Feminists), a constituency recognized as advocates for gender parity and allied with the Democratic party (Green, Palmquist and Schickler 2004). Similarly, to gauge attitudes toward gay rights in general (as opposed to only same-sex marriage in particular), I use the favorability of 'gay and lesbian organizations' (Favor Gay Groups). Finally, I include responses to an item asking respondents to describe their 'political views,' (Ideology) with responses on a five-point scale ranging from 'very conservative' (1) to 'very liberal' (5). ${ }^{7}$

\footnotetext{
${ }^{6}$ The Bush-Kerry Favorability scale has a Cronbach's alpha of .90, indicating high reliability. The reliability coefficients for the constituent scales are .93 (Kerry items) and .92 (Bush items).

${ }^{7}$ Ideology and Gay Marriage are the only items that were included in each wave of the NAES rolling crosssection, from October 7,2003-November 16, 2004. The schedule for the other items was as follows: Abortion (10/7/03-9/20/04); Vouchers (10/7/03-9/19/04); Favor Feminists (10/7/03-6/24/04, for two-thirds of the sample; 6/25/04-8/19/04, for one-quarter of the sample); Favor Gay Groups (10/7/03-6/24/04, for twothirds of the sample; $6 / 25 / 04-9 / 19 / 04$, for one-quarter of the sample) Other social policy items, e.g. stem cell research, available in the NAES were not included in this analysis because the items appeared in too few waves and/or were asked of only a small subsample of the black respondents.
} 
Following Bartels (1996) and others, I measure levels of political knowledge using the survey interviewer's assessment (Treier and Hillygus 2009). The measure reflects a broad judgment, reached by the interviewer at the conclusion of the survey, about 'how knowledgeable the respondent was about politics.' Zaller (1986), in a detailed analysis of a similar measure on the American National Election Study, showed interviewer ratings to be 'highly effective as measures of political information,' comparable in discriminating power to a 'Cadillac information scale' constructed from 27 different factual knowledge questions, and 'essentially free of contamination by interviewers who might be biased in favor of higher status respondents.' Similarly, Luskin $(1987,885)$ demonstrates that even for his most elaborate information scale, built from more than 30 objective indicators, one of the most strongly correlated criterion variable is the interviewer rating $(r=.60)$, second only to placement of political actors on the liberal-conservative spectrum $(r=.73)$. In addition to their general reliability as measures of political knowledge, the interviewer ratings are useful proxies in this analysis since the NAES rolling cross-section includes few factual knowledge questions asked across multiple waves of the survey. Political knowledge ratings based on responses to the four factual questions asked most often can be constructed for only a small subset $(\mathrm{N}=2463)$ of the NAES Black respondents. For this subset, the four-item factual knowledge score and the interviewer rating correlate at .49, a predictably weaker correlation than Luskin (1987) or Zaller (1986) uncovered using their more robust, multi-item factual knowledge scales. ${ }^{8}$ The interviewer ratings, which are available for every NAES respondent and have been shown to be both valid and efficient, are preferable to the four-item scale as a measure of respondents' general political knowledge. ${ }^{9}$

\footnotetext{
${ }^{8}$ The Cronbach's alpha for the four-item factual knowledge scale is .58.

${ }^{9} \mathrm{I}$ have replicated this analysis using respondents answers to the series of four factual knowledge questions. (The factual knowledge questions asked the respondent to identify then-Vice President Dick Cheney; the role of the Supreme Court; the votes required to override a presidential veto; and the majority party in the House of Representatives.) The results are substantively unchanged, though more pronounced. Althaus (2003) constructs knowledge scales that combine the subjective interviewer assessment with factual items (see also Claassen and Highton (2009); Zaller (1992)). A similar approach, if pursued here, would reduce the sample size by two-thirds, from 6550 to 2463 black respondents. The reliability of interviewer ratings makes that approach unnecessary.
} 
The main disadvantage of the interviewer assessment is its generality. The rating is an imprecise measure of the specific type of political knowledge-namely, knowledge of partisan cleavages on social issues - that I theorize moderates the relationship between African Americans' partisan commitments and their policy views. Measures of respondents' ability to discern the differences in the social issue positions of the major parties and candidates are available for only $12 \%$ of black NAES respondents, too few to permit meaningful statistical analysis. ${ }^{10}$ However, Zaller (1986)'s evidence suggests that a respondent's level of political information 'is a relatively general trait,' such that 'someone who is well-informed on one subject is very likely to be well-informed on others as well.' From this he concludes that a general-purpose information scale, like interviewer assessment, can be as effective as domain-specific information measures. By this logic, it is reasonable to believe that a respondent viewed as well-informed across the wide range of political subjects covered in the NAES interview, is likely to be well-informed on political subjects not covered, such as party positions on issues like abortion, gay rights and women's role in society.

The interviewer's letter-grade assessment of knowledge was on a five-point scale, ranging from 1 ('F,' low knowledge) to 5 ('A,' high knowledge). The grade distribution for black respondents has a mean of 3.51 (between a 'B' and a 'C'), with a majority of the respondents $(61 \%)$ clustered in the middle regions, receiving scores of 3 or 4 . About $18 \%$ of respondents were clustered in the two lowest knowledge categories, with grades of ' $\mathrm{D}$ ' or ' $\mathrm{F}$.' The distribution is not so negatively skewed as to raise concerns about ceiling effects from high average information scores. Also, consistent with earlier studies (Althaus 2003; Bartels 1996; Luskin 1987; Zaller 1986), a regression of interview ratings on demographic and political variables finds that scores correlate predictably with education, income, gender, political interest, political discussion, voter registration and turnout. ${ }^{11}$

In the analysis below, I report the results of models in which partisan attitudes are

\footnotetext{
${ }^{10}$ In a few waves of the survey (between 9/21/04-11/16/04), a random subset of the cross-section was asked about the positions of presidential candidates on abortion. Eight hundred and forty-seven Black respondents received this question.

${ }^{11}$ Analysis available from author upon request.
} 
regressed on social issue opinions and political knowledge. For the binary dependent variables (Bush Vote, Bush Job) I estimate logit models; for Party ID and Bush-Kerry Favorability, I estimate OLS models. Each regression model includes only one of the six social issue indicators as a predictor. Excluded from the models are other attitudinal variables that are not plausibly exogenous to levels of political information or to the given social issue under study; by omitting such variables we capture the full 'effect' of a given social issue, conditional on information. ${ }^{12}$ Each model includes controls for demographic covariates (Gender,Age, Education, Income), as they are relatively stable features of a respondent's makeup and may bear on their partisan attitudes, and for interview date. Table 1 reports descriptive statistics on all measures, stratified by interviewer's assessment of the respondent's level of political knowledge.

[Table 1 about here.]

\section{How Information Moderates the Policy-Party Link}

When examined in the aggregate, without taking levels of political knowledge into account, there is little relationship between Blacks' social issue positions and their partisan attitudes. This correlational pattern is evident in Figure $1(\mathrm{a})-(\mathrm{d})$, which report the change in expected partisan identification (a), candidate favorability (b), presidential job approval (c) and vote choice (d) given a change in policy view from the $25^{\text {th }}$ percentile to the $75^{\text {th }}$ percentile position, with demographic covariates (gender, age, education, income) and interview date held constant at mean values. ${ }^{13}$ A label next to each point estimate identifies the policy area. Not only do African-American partisan attitudes exhibit a strong pro-

\footnotetext{
${ }^{12}$ These parsimonious models are not meant to predict individual-level partisan attitudes. Rather, the models are intended to capture differences in partisan attitudes between social conservative and social liberals, under conditions of low- or high-information.

${ }^{13}$ Each graph reports the first differences simulated based on the results from six separate regressions, each estimating the relationship between a given partisan attitude (e.g. Party ID in Figure 1(a)) and one of the social issue indicators, controlling for demographic covariates and interview date. To avoid out-ofsample predictions, I simulate first differences using values that appear in the dataset (i.e. the $25^{\text {th }}$ and $75^{\text {th }}$ percentile positions), rather than the minimum and maximum of a given scale.
} 
Democratic/anti-Republican bias in general (i.e. see sample means in Table 1), this bias persists even among those who hold conservative views on social issues. The first differences, and accompanying 95\% confidence intervals, are near zero in almost every case, indicating that there is little to no change in partisan attitudes as abortion (abort), gay marriage (marr) or school voucher (voucher) views change from liberal to conservative; as opinion about feminists (fem) and about gay and lesbian groups (gays) change from less to more favorable; and as self-described ideology (ideo) changes from 'liberal' to 'conservative.' This pattern of small differences between social liberals and social conservatives is consistent with the claim that racial concerns are highly salient, perhaps dominant, in African Americans' political decision-making. ${ }^{14}$

[Figure 1 about here.]

However, once you separate the relationship of policy views to partisan attitudes among the politically informed from the same relationships among the uninformed, we begin to see the extent to which the strength of Democratic commitments is sustained not only by the bond of race, but also by low knowledge. I estimated a series of models that included, in addition to the measures of information and policy views, the interaction of views and information. ${ }^{15}$ (The models also controlled for gender, age, education, income and interview date.) Information, measured by the interviewers assessment of respondent political knowledge, enters the models as four indicator variables (with low knowledge, 'F,' as the omitted category), each interacted with policy views, thus allowing for the possibility that the policy-party relationship does not vary monotonically with information.

As a first test of whether information moderates policy-party relationships, I compare the fit of the unrestricted models, which include information and policy-information interaction

\footnotetext{
${ }^{14}$ The 2004 NAES did not include items measuring racial attitudes (e.g racial linked fate). As a result, it is not possible to model the relationship between racial and partisan attitudes, and examine this claim directly.

${ }^{15}$ A total of 24 models were estimated, six for each of the four dependent variables (Party ID, Bush Job, Bush Vote, Bush-Kerry Favorability). In each of the six models, a given dependent variable was regressed on either Abortion, Gay Marriage, Vouchers, Favor Feminists, Favor Gay Groups or Ideology, in addition to information, the policy-information interaction terms, demographic covariates and interview date.
} 
terms, to the fit of the earlier, restricted models, which excluded information (and the interaction terms) from the set of predictors. I perform likelihood ratio tests to assess relative fit (Bartels 1996; Althaus 2003). In 16 out of 24 tests (67\%), the unrestricted models that allow for information effects produce statistically significant improvements in fit, at the $p<.05$ level, over models that exclude information. In other words, contrary to the assumptions of the restricted model, informed and uninformed blacks often differ in the extent to which they align their policy views and partisan attitudes. Of the partisan attitudes examined here, likelihood ratio tests find evidence of information effects most frequently in the models predicting Bush-Kerry Favorability and Bush Job approval; in 12 of 12 tests of model fit, the observed difference between the restricted and unrestricted models is statistically significant at the $p<.05$ level. ${ }^{16}$

To translate the regression results into quantities of interest, I simulate the difference in the partisan attitudes we would expect to observe if ideology or opinions on abortion, same-sex marriage or school vouchers were more conservative, or if affect toward feminist or gay and lesbian organizations were more favorable. In each simulation, views shift from the $25^{\text {th }}$ percentile position to the $75^{\text {th }}$ percentile (while holding other covariates constant at mean values). I simulate the change in expected value at each level of political knowledge. If political knowledge moderates the policy-party relationship as hypothesized, then the size of the simulated differences should vary with political knowledge, with larger differences among those with higher levels of information.

Figure 2 reports the expected change in party identification (Party ID) associated with a $25^{\text {th }}$-to- $-75^{\text {th }}$ percentile change in social views, for each social view (ideo, abort, marr, voucher, fem, gays) - for the 'whole sample' of Black respondents (at top of graph) and for Black respondents at each level of political knowledge. In addition to the point estimates, the graph also depicts the $95 \%$ confidence intervals for the estimates. The graph reveals that

\footnotetext{
${ }^{16}$ For the models of Party ID, 3 of 6 likelihood ratio tests identify statistically significant differences in the fit of restricted and unrestricted models; for Bush Vote, 1 of 6 tests identify statistically significant improvements in model fit.
} 
the policy-party correlation is strongest among the highly informed. For African Americans at the lowest two levels of political knowledge - those who earned grades of ' $D$ ' or ' $F$ ' from their survey interviewers - social views and party identification are unrelated to one another. Point estimates of the expected change in party identification associated with a change in social views are at or near zero in almost every case, and the $95 \%$ confidence intervals consistently include zero. By comparison, among the most informed Blacks (i.e. those who earned grades of 'A' or 'B'), a change in social conservatism across the inter-quartile range is associated with a statistically significant change in party identification in almost every case. Ideology, abortion views and affect toward feminist organizations stand out in particular for their relationship to party identification among the politically knowledgeable. For the most knowledgeable Blacks, holding other covariates constant at mean values, party identification changes by -.73 [-.91,-.55] when self-described ideology changes from 'liberal' to 'conservative'; by -.41 [-.61,-.20] when abortion views change from 'strongly oppose' to 'somewhat favor' a total ban; and by .35 [.19,.53] when the favorability of feminist organizations increases by three points, on a scale from 0 to 10. These differences, together with differences associated with changes in the favorability of gay and lesbian organizations and in support for same-sex marriage and school vouchers, though substantively modest, are nonetheless consistent with the claim that the alignment of party and social issue positions depends on information.

[Figure 2 about here.]

Figures 3 - 5 display the expected differences and $95 \%$ confidence intervals for the other three partisan attitudes-Bush-Kerry Favorability, Bush Job, Bush Vote. A consistent pattern emerges. At low levels of political knowledge, Black (social) liberals and conservatives are indistinguishable in their job approval ratings (Figure 4) and electoral support (Figure 5) for Bush. Furthermore, these politically distinct, though equally poorly informed, groups are similar in their judgements about the favorability of President Bush relative to John Kerry (Figure 3). With point estimates and confidence intervals consistently at or near zero, the results make clear that views on social issues - from opposition to gay marriage and 
abortion rights to support for school vouchers to disapproval of feminist and gay and lesbian organizations - are not predictive of partisan attitudes among those Black respondents who earned knowledge grades of ' $\mathrm{D}$ ' or ' $\mathrm{F}$.' But as we move up the grade scale to the segment of politically knowledgeable Blacks, point estimates and confidence intervals move away from zero: Just as informed social liberals and conservatives differ in their party identification (Figure 2), they also differ from each other in their evaluations of and electoral support for Bush. For example, for the most knowledgeable Blacks, a change in abortion views from 'strongly oppose' to 'somewhat favor' an abortion ban increases the relative favorability of Bush over Kerry (Figure 3) by 1.69 [1.22,2.15], on a scale from -10 to +10 ; the probability of approving of Bush's job performance (Figure 4) by .11 [.07,.15]; and the probability of a Bush

vote (Figure 5) by .08 [.05,.12]. Across the 48 policy-party relationships examined among the politically informed (Grade 'A' or 'B'), each estimated controlling for demographic covariates and interview date, all but seven are statistically significant. By comparison, of the 48 policy-party relationships among the least informed (Grade 'D' or 'F'), all but 2 are statistically insignificant. In short, African Americans whose views on social issues are at odds with the Democratic Party, if they are knowledgeable enough to recognize the conflict, are less likely than their equally informed but more liberal counterparts to maintain strong Democratic commitments. The partisan implications of policy views depend on political knowledge.

[Figures $3-5$ about here.]

\section{When Information Matters Most}

Black Americans whose social issue opinions put them at odds with the Democratic party express weaker Democratic commitments, provided they are sufficiently politically informed. But, when it comes to policy disagreement, are all Blacks equally responsive to political information? Or, does the value of political information for bringing partisan and policy views into alignment vary across individuals, in particular with the relative importance 
of social issues? Van Knippenberg and Daamen (1996) identify motivation as critical to information-processing, showing that individuals who are more involved with an issue are more likely to use information in order to form stable and consistent policy preferences on that issue. Thus, we might reasonably expect information to matter primarily for those Black Americans for whom social issues like abortion and same-sex marriage are highly salient; relative to others, this group is likely to be more concerned with reconciling their partisan attitudes with their social views and, thus, more likely to use information to "get it right"

To answer this question, I consider how information effects vary with church attendance and religious tradition. In the absence of more precise measures of issue importance, I use the frequency of church attendance and self-identification as a born-again or evangelical Christian as indicators of the salience of social issues. Verba, Schlozman and Brady (1995, Chapter 14) link church involvement not only to more conservative views on abortion (see also Ellison, Echevarra and Smith (2005)), but also to a much greater propensity to engage in issue-based political activity, one sign of issue importance; in fact, their 'church variables' are stronger predictors of participation in abortion-related politics than is holding extreme views on this social issue. (Importantly, church activity does not predict greater political engagement on other issues, such as education or social welfare. $)^{17}$

For African Americans, church attendance alone may not be sufficient as an indicator of the importance of moral and social issues, as the dominant theological traditions in black churches put a strong emphasis on socially progressive themes of fairness and equality (Harris 1999). ${ }^{18}$ The scriptural interpretations embraced by black Evangelicals, however, stress not only the imperative of justice but also personal piety and moral conduct (McDaniel and Ellison 2008). We might plausibly assume, therefore, that black Evangelical churchgoers will

\footnotetext{
${ }^{17}$ Analysis of Black NAES respondents demonstrates that frequent churchgoers are statistically significantly less likely to offer 'Don't Know' or 'Neither Favor Nor Oppose' responses to the policy items, a pattern consistent with the higher salience of social issues among the religiously active. Regression results available from author upon request.

${ }^{18} \mathrm{I}$ credit an anonymous reviewer for this insight.
} 
be more concerned than others with issues such as abortion and same-sex marriage and more committed to bringing their politics and their moral values into alignment (Layman 2001). Thus, if issue importance matters, I expect information effects to be concentrated among the $39 \%$ of NAES Black respondents who identify as born-again or evangelical Christians and attend religious services at least once per week. ${ }^{19}$

Figures $6-9$ report the results of regressions in which partisan attitudes were modeled as a function of interactions between policy views, information and church attendance, separately by religious tradition (born-again/evangelical or not). To simplify the three-way interactions between policy, information and church attendance, I recoded the information measure to two binary indicators: high knowledge (Grade 'A' or 'B'), low knowledge (Grade 'D' or 'F'), with Grade ' $\mathrm{C}$ ' the excluded category. The graphs display the expected difference in partisan attitude associated with a change in policy view from the $25^{\text {th }}$ percentile to the $75^{\text {th }}$ percentile position, given a particular level of church attendance - at least once per week (solid dot), or less (hollow dot) — for high knowledge (solid lines) and low knowledge (dash lines) respondents. In each graph, the left panel displays the expected differences for non-Evangelicals; the right panel, for Born-Again and Evangelical Christians.

[Figures $6-9$ about here.]

Across each of the graphs, the patterns for black Evangelicals (right) and non-Evangelicals (left), for frequent (solid dot) and infrequent (hollow dot) churchgoers are similar: At low levels of political knowledge, the estimated change in partisan attitude associated with a change in social issue position is typically at or near zero, with $95 \%$ confidence intervals (dash lines) that include zero. At high levels of political knowledge, the estimated change in partisan attitude is more often non-zero and statistically significant (solid lines). These broad patterns can be seen more clearly in Table 2, which summarizes, for each subgroup of respondents (as defined by evangelicalism, church attendance and level of knowledge), the number of times

\footnotetext{
${ }^{19}$ Sixty-one percent of Black respondents identify as born-again or evangelical Christians, a figure consistent with McDaniel and Ellison (2008, 182-183)'s claim that 'African Americans are much more likely than Anglos to hold orthodox theological beliefs.' Nearly two-thirds of black evangelicals report attending church one or more times per week, compared with only $30 \%$ of non-evangelicals.
} 
that the expected difference in partisan attitude associated with a change in policy view is statistically significant at the $p<.05$ level. (For each respondent subgroup, I calculate a total of 24 (6 policy positions x 4 partisan attitudes) policy-party relationships.) Among low-knowledge non-Evangelicals, at all levels of church attendance, only $4.2 \%$ of the (48) estimated policy-party relationships are statistically significant, compared with $52.1 \%$ among high-knowledge non-Evangelicals. For black Evangelicals, the difference in the number of statistically significant policy-party correlations between those who received knowledge grades of ' $\mathrm{D}$ ' or ' $\mathrm{F}$ ' and those who received grades of ' $\mathrm{A}$ ' or ' $\mathrm{B}$ ' is also substantial: $10.4 \%$ versus $70.8 \%$, respectively, of the policy-party relationships are statistically significant. A similar pattern holds if we disaggregate further to compare low- and high-knowledge respondents within levels of church attendance. ${ }^{20}$ In other words, for the politically uninformed, policy views and partisan attitudes are almost always uncorrelated, even among those who presumably care about getting it right (i.e. black Evangelicals, frequent churchgoers). And for the politically informed, policy and party are typically correlated, even among those for whom social issues are relatively less salient (i.e. black non-Evangelicals, infrequent churchgoers). As a rule, the more African Americans know about politics, the more aligned are their policy views and partisan attitudes.

[Table 2 about here.]

But while political knowledge matters in general, regardless of religious tradition or frequency of church attendance, it matters more consistently for black Evangelicals than it does for non-Evangelicals. Whereas nearly $71 \%$ of the policy-party relationships are statistically significant among high-knowledge Evangelicals, only $52 \%$ are significant among high-knowledge non-Evangelicals. Still further, it is the most committed black Evangelicals, as measured by the frequency of church attendance, for whom information matters most often. Ninety-five percent (23 of 24) of the policy-party relationships among religiously

\footnotetext{
${ }^{20}$ For example, among low knowledge, low-church attendance Evangelicals, in only 1 of 24 cases is a change in policy view associated with a statistically significant difference in partisan attitude. For high-knowledge, low- church attendance Evangelicals the figure is 11 of 24.
} 
active, highly informed Evangelicals are statistically significant, compared with $46 \%$ (11 of 24) among black Evangelicals who are less active but nonetheless highly informed. Thus, the empirical results demonstrate that (1) knowledge matters, but (2) it matters most when social issues are salient.

\section{The Ties That Bind: Comparing Information and Race}

To find that differences in social policy views are associated with statistically significant differences in partisan attitudes, but only if blacks are sufficiently politically knowledgeable (and especially when social issues are salient), demonstrates the importance of information as a moderator in the policy-party relationship - a fact consistent with prior research on political knowledge (Claassen and Highton 2009; Converse 1964; Delli Carpini and Keeter 1996; Lauderdale 2010), though previously unrecognized in the literature on black partisanship. Blacks' Democratic allegiance is, in part, a function of low information. At the same time, for well-informed Blacks, the policy-party linkages are substantively modest-more modest than the literature on information effects, based almost exclusively on the analysis of white public opinion, might lead us to predict. Even the most strongly cross-pressured Blacks - those who favor a total ban on abortion, oppose gay marriage, view feminists and gay and lesbian activists unfavorably and so on- evince a pro-Democratic bias not that different from the attitudes of pro-choice liberals who favor marriage equality. As scholars of black politics have long argued, this likely reflects the continuing salience of race and racial concerns in African-American political decision-making.

The 2004 NAES does not include items probing the racial attitudes of respondents, which limits our ability to directly assess the extent to which such issues account for the resilience of African Americans' Democratic commitments across information strata. ${ }^{21}$ However, we can examine the policy-party relationship, and how it varies with political knowledge, among a

\footnotetext{
${ }^{21}$ The 2004 NAES includes neither measures of racial policy preferences (e.g. opinion toward affirmative action) nor measures of racial group consciousness (e.g. racial linked fate).
} 
group for whom race is relatively less salient to political decision-making: white Americans. If race is the reason we observe modest policy-party relationships even among politically knowledgeable Blacks, then we should find greater policy-party alignment among whites than we do Blacks. That is, the change in partisan attitude associated with a change in social issue positions should be substantively larger for the group less bound by racial commitments.

Figure 10 reports the results of models that replicate for white respondents the main analysis conducted earlier for Blacks. In particular, each graph depicts the expected difference in partisan attitudes associated with a change in policy view from the $25^{\text {th }}$ percentile to the $75^{\text {th }}$ percentile Black position, for white respondents at each grade-level of political knowledge. ${ }^{22}$ (I use the percentile benchmarks for Black respondents to facilitate comparison of the two racial groups.) The shape of the graphs are quite similar to what was observed in the earlier analysis (Figures $2-5$ ); there is a consistent pattern of stronger policy-party relationships, with point estimates and 95\% confidence intervals further away from the zero-line, at higher levels of political knowledge. But, for our purposes, the critical difference between the two sets of figures is the magnitude of the policy-party correlations for whites as compared to Blacks. A similar change in social policy opinion is associated with a much larger change in partisan attitudes for whites than for Blacks. As one example, among the most informed respondents (Grade 'A'), a change in position regarding a constitutional amendment to ban gay marriage from 'strongly oppose' to 'strongly favor' changes white partisan identification by -2.07 [-2.15, -1.99] on a seven-point scale, but Black partisan identification not at all; whites' probability of approving of Bush's job performance by .46 [.44, .47], but Blacks' probability by .10 [.06, .15]; whites' probability of voting for Bush by .50 [.48,.51], but Blacks' probability by .10 [.06, .15]; and the relative favorability of Bush over Kerry among whites by $5.86[5.68,6.03]$, but among Blacks by only $1.27[.77,1.77]$.

\footnotetext{
${ }^{22}$ The political knowledge scale for white NAES respondents has a mean (standard deviation) of 3.81 [1.03], with $65.5 \%$ of respondents scoring grades of A or B and $10.5 \%$ of respondents scoring grades of D or F. (The figures for blacks are $53.5 \%$ and $17.9 \%$, respectively.)
} 
[Figure 10 about here.]

The greater alignment of policy and party among whites than among Blacks, at every level of political knowledge, is consistent with the claim that racial concerns loom large in Black political decision-making; the salience of racial group interests inhibits partisan drift as policy preferences diverge, and constrains information effects among blacks. Moreover, the differences in policy-party alignment between similarly-informed Blacks and whites, i.e. the

race 'effect,' exceed the differences between Blacks at the top and bottom of the knowledge scale, i.e. the information 'effect.' The implication is that race is a more significant moderator than is information in the policy-party relationship. Notably, these insights are revealed only with the juxtaposition of white and black public opinion, an analytical perspective that is as unusual in the literature on political knowledge as is attention to political knowledge in the literature on black partisanship. The juxtaposition yields evidence that both affirms and challenges the core claims of these literatures: knowledge does matter for black partisan attitudes, but it matters far less than it does for the (less racially-committed) white mass public.

\section{Conclusions}

Opinions on social issues are relevant to Black partisan attitudes, but only when Blacks are sufficiently knowledgeable to connect these views to partisan judgements. In the absence of political knowledge, social issues have no partisan relevance, even among religiously active black Evangelicals for whom issues such as abortion and gay rights are typically more salient; a pro-Democratic bias can persist in spite of divergent social views. Information magnifies the partisan implications of social issue cleavages, as predicted in the literature on political knowledge (Claassen and Highton 2009; Converse 1964; Lauderdale 2010). For highly informed blacks, conservative [liberal] social issue positions are associated with less [more] favorable attitudes toward the Democratic Party. This effect is not limited to committed Evangelicals but is most pronounced among them. While less informed Blacks are 
firmly anchored to the traditional group loyalties inherited from the civil rights period, the well-informed appear more attentive to the social liberalism of the contemporary Democratic party (Bartels 1996).

Low knowledge, however, is not the only force sustaining African Americans' Democratic commitments. Even well-informed black social conservatives hold generally favorable views of Democrats and unfavorable views of Republicans. True, policy cross-pressures impact black public opinion, but only on the margins. It is likely that Black Americans' racial commitments are what inhibit greater policy-party alignment on social issues, as argued by scholars of black politics (Dawson 1994). Deep concerns over persistent racial inequality, together with the belief that the Democratic Party is more supportive of the black agenda (Philpot 2007), may effectively override cross-pressures related to social issue positions. Comparisons to white Americans, among whom we observe substantially more policy-party alignment at all levels of political knowledge, underscore the centrality of race as an animating force in Black partisan attitudes. The findings lay bare the limits on Republican efforts to recruit African Americans into the party. The challenge is not simply to boost awareness of shared values on social and cultural issues (particularly among committed black Evangelicals); such policy agreements are associated with only small, albeit statistically significant, differences in partisan judgments. Knowledge helps, but in the end recruitment may depend on a 'return of the party of Lincoln' (Philpot 2007). This practical insight emerges only when we bridge two literatures - one on black public opinion, the other on political knowledge - that rarely intersect.

Questions remain. The findings from this research, based on evidence from the analysis of observational data, can only establish the plausibility of an information hypothesis, i.e. that more information about the nature of partisan cleavages would lead to greater social policy-party alignment. Without the benefit of experimental data, it is not possible to isolate the causal effect of information, as decisions about whether to become informed about politics may be endogenous to political beliefs or other relevant background characteristics. 
Without measures of information-holding more precise, and less subjective, than interviewer ratings, it is not possible to distinguish the effects of factual information about party positions from the broader effects of the distinctive cognitive styles and information-processing strategies adopted by politically knowledgeable citizens (Althaus 2003; Sniderman, Brody and Tetlock 1993; Zaller 1992). ${ }^{23}$ The most well-informed black respondents on the NAES, as judged by the survey interviewers, may not only know more about politics than others, they may be more sophisticated in their thinking about politics as well. Finally, given data in which positions on social issues and partisan attitudes are measured simultaneously, it remains unclear whether partisan evaluations follow policy opinions, or the reverse. Either is technically possible. Gilens and Murakawa (2002), in particular, presents experimental evidence that partisan cues have causal effects on expressed policy preferences - that is, people bring their policy views into line with their standing partisan commitments. This is likely to be the case more generally for low-salience issues, such as food irradiation (Kam 2005). Whether policy follows party on salient social issues such as gay marriage and abortion is less clear. Nonetheless, relying on non-experimental, cross-sectional data limits our ability to say conclusively whether information leads individuals to bring their partisan attitudes into line with their policy views. More modestly, the findings here demonstrate that individuals who are more politically informed are more likely to reconcile their partisan and social issue attitudes.

Future work should identify the causal effect of information-holding, by testing whether informational interventions can reduce the discrepancies between Blacks' policy views and their partisan commitments. Attention should focus, in particular, on providing experimental subjects with information about the partisan alignment of social issues. Equally important is the need for direct indicators of subjects' racial attitudes and beliefs, which I hypothesize

\footnotetext{
${ }^{23}$ The subjectivity of the interviewer ratings also means that it is not possible to establish with certainty a respondent's command of factual information about politics, although factual knowledge and interviewer ratings are shown above to be positively correlated (for the subset of respondents who were asked factual knowledge questions). Respondents judged by the interviewer to be uninformed about politics, and who exhibit a weak party-policy relationship, may misperceive party positions or be unaware of them. I credit an anonymous reviewer for this insight.
} 
to override social issue cross-pressures among Blacks. In short, the design should take seriously both race and information as influences on black partisanship. Does learning about the partisan alignment of issues lead Black Americans to adopt more consistent partisan attitudes, or is their allegiance to Democratic partisanship resistant to new information? To what extent do the party's historical commitment to racial equality and Blacks' own sense of racial group consciousness limit the impact of social issue cross-pressures, even among the (newly) informed? Experimental evidence can bolster the more tentative answers offered here. 


\section{References}

Abramowitz, Alan. 2010. The Disappearing Center: Engaged Citizens, Polarization, and American Democracy. Yale University Press.

Althaus, Scott L. 2003. Collective Preferences in Democratic Politics: Opinion Surveys and the Will of the People. Cambridge University Press.

Bartels, Larry M. 1996. "Uninformed votes: Information effects in presidential elections." American Journal of Political Science 40(1):194.

Claassen, Ryan L. and Benjamin Highton. 2009. "Policy Polarization among Party Elites and the Significance of Political Awareness in the Mass Public." Political Research Quarterly $62(3): 538-551$.

Converse, Phillip E. 1964. The Nature of Belief Systems in Mass Publics. In Ideology and Discontent, ed. David E. Apter. New York, NY: Free Press pp. 206-261.

Dawson, Michael C. 1994. Behind the Mule: Race and Class in African-American Politics. Princeton, N.J.: Princeton University Press.

Delli Carpini, Michael X. and Scott Keeter. 1996. What Americans Know About Politics and Why it Matters. New Haven, CT.: Yale University Press.

Ellison, Christopher G., Samuel Echevarra and Brad Smith. 2005. "Religion and Abortion Attitudes Among U.S. Hispanics: Findings from the 1990 Latino National Political Survey." Social Science Quarterly 86(1):192 - 208.

Frymer, Paul. 1999. Uneasy Alliances: Race and Party Competition in America. Princeton, NJ.: Princeton University Press.

Galston, William A. 2001. "Political Knowledge, Political Engagement, and Civic Education." Annual Review of Political Science 4(1):217-234.

Gilens, Martin. 2001. "Political Ignorance and Collective Policy Preferences." American Political Science Review 95(2):379.

Gilens, Martin and Naomi Murakawa. 2002. Elite Cues and Political Decision-Making. In Research in Micropolitics: Political Decision-Making, Deliberation and Participation, ed. Michael X. Delli Carpini, Leonie Huddy and Robert Shapiro. New York, NY.: JAI Press pp. $15-50$.

Green, D.P., B. Palmquist and E. Schickler. 2004. Partisan Hearts and Minds: Political Parties and the Social Identities of Voters. New Haven, CT.: Yale University Press.

Hajnal, Zoltan and Taeku Lee. 2011. Why Americans Don't Join the Party: Race, Immigration and the Failure (of Political Parties) to Engage the Electorate. Princeton, N.J.: Princeton University Press. 
Harris, F.C. 1999. Something Within: Religion in African-American Political Activism. Oxford University Press.

Harris-Lacewell, Melissa V. 2004. Barbershops, Bibles, and BET: Everyday Talk and Black Political Thought. Princeton, N.J.: Princeton University Press.

Kam, Cindy. 2005. "Who Toes the party Line? Cues, Values, and Individual Differences." Political Behavior 27(2):163 - 182.

Kinder, Donald R. 2001. "Exploring the Racial Divide: Blacks, Whites, and Opinion on National Policy." American Journal of Political Science 45(2):439.

Kuklinski, James H. and Norman L. Hurley. 1994. "On Hearing and Interpreting Political Messages: A Cautionary Tale of Citizen Cue-Taking." The Journal of Politics 56(3):pp. $729-751$.

Lauderdale, Benjamin E. 2010. "Does Congress Represent Public Opinion As It Is Or As It Might Be?" Presented at the Annual Meeting of the American Political Science Association.

Layman, G. 2001. The Great Divide: Religious and Cultural Conflict in American Party Politics. New York, NY.: Columbia University Press.

Luskin, Robert C. 1987. "Measuring Political Sophistication." American Journal of Political Science 31(4):pp. 856-899.

McDaniel, Eric L. and Christopher G. Ellison. 2008. "God's Party? Race, Religion, and Partisanship over Time." Political Research Quarterly 61(2):180-191.

Philpot, Tasha S. 2007. Race, Republicans, 83 the return of the party of Lincoln. Ann Arbor, MI.: University of Michigan Press.

Smith, R. Drew. 2005. Black Clergy and the Governmental Sector During George W. Bush's Presidency. In Black Churches and Local Politics: Clergy Influence, Organizational Partnerships, and Civic Empowerment, ed. R. Drew Smith and Frederick C. Harris. Lanham, MD.: Rowman \& Littlefield pp. 187-216.

Sniderman, Paul M., Richard A. Brody and Phillip Tetlock. 1993. Reasoning and Choice: Explorations in Political Psychology. New York, NY.: Cambridge University Press.

Tate, Katherine. 2010. What's Going On?: Political Incorporation and the Transformation of Black Public Opinion. Washington, D.C.: Georgetown University Press.

Treier, Shawn and D. Sunshine Hillygus. 2009. "The Nature of Political Ideology in the Contemporary Electorate." Public Opinion Quarterly 73(4):679-703.

Van Knippenberg, Daan and Dancker Daamen. 1996. "Providing Information in Public Opinion Surveys: Motivation and Ability Effects in the Information-and-Choice Questionnaire." International Journal of Public Opinion Research 8(1):70-82. 
Verba, Sidney, Kay L. Schlozman and Henry E. Brady. 1995. Voice and Equality: Civic Voluntarism in American Politics. Cambridge, MA.: Harvard University Press.

Zaller, John. 1986. "Analysis of Information Items in the 1985 ANES Pilot Study." ANES Pilot Study Report, No. nes002261.

Zaller, John. 1992. The Nature and Origins of Mass Opinion. New York, NY.: Cambridge University Press. 


\begin{tabular}{|c|c|c|c|c|c|}
\hline \multirow[b]{2}{*}{ Variable } & \multicolumn{5}{|c|}{ Respondent Political Knowledge Grade } \\
\hline & A & $\mathrm{B}$ & $\mathrm{C}$ & $\mathrm{D}$ & $\mathrm{F}$ \\
\hline \multicolumn{6}{|l|}{ Partisan Attitudes } \\
\hline Party Identification & 5.89 & 6.00 & 6.04 & 5.80 & 5.80 \\
\hline [1(Strong Republican), 7(Strong Democrat)] & $(1.57)$ & $(1.50)$ & $(1.51)$ & $(1.70)$ & $(1.72)$ \\
\hline Bush-Kerry Favorability & -3.81 & -3.65 & -3.44 & -3.15 & -2.49 \\
\hline$[-10,+10]$ & $(4.05)$ & $(3.95)$ & $(3.79)$ & $(4.02)$ & $(3.91)$ \\
\hline Approve Bush Job Performance & .17 & .19 & .20 & .24 & .24 \\
\hline Vote for Bush & .09 & .11 & .09 & .09 & .12 \\
\hline \multicolumn{6}{|l|}{ Social Issues } \\
\hline Abortion Ban & 2.14 & 2.27 & 2.33 & 2.52 & 2.71 \\
\hline [1(Strong Oppose), 5(Strong Favor)] & $(1.52)$ & $(1.59)$ & $(1.63)$ & $(1.66)$ & $(1.74)$ \\
\hline Gay Marriage Ban & 2.62 & 2.80 & 2.73 & 2.70 & 2.94 \\
\hline [1(Strong Oppose), 5(Strong Favor)] & $(1.74)$ & $(1.76)$ & $(1.77)$ & $(1.73)$ & $(1.78)$ \\
\hline School Vouchers & 2.93 & 3.12 & 3.30 & 3.41 & 3.45 \\
\hline [1(Strong Oppose), 5(Strong Favor)] & $(1.76)$ & $(1.73)$ & $(1.72)$ & $(1.69)$ & $(1.70)$ \\
\hline Favor Feminists & 5.80 & 5.97 & 5.80 & 5.88 & 5.35 \\
\hline$[0,10]$ & $(2.70)$ & $(2.63)$ & $(2.76)$ & $(2.866)$ & $(3.13)$ \\
\hline Favor Gay Groups & 3.86 & 3.61 & 3.12 & 3.00 & 2.90 \\
\hline$[0,10]$ & $(3.04)$ & $(3.24)$ & $(3.14)$ & $(3.23)$ & $(3.16)$ \\
\hline Ideology & 2.91 & 3.00 & 3.10 & 3.13 & 3.27 \\
\hline [1(Very Liberal), 5(Very Conservative)] & $(.96)$ & $(1.02)$ & $(1.04)$ & $(1.09)$ & $(1.19)$ \\
\hline Number of Respondents & 1383 & 2105 & 1873 & 812 & 353 \\
\hline
\end{tabular}

Table 1: Variable Descriptions. 2004 National Annenberg Election Study, Rolling CrossSection. Cell entries in Columns $2-6$ are means (standard deviations), by interviewer's assessment of respondent's level of political knowledge. Black Respondents only. 


\begin{tabular}{ll|cc}
\hline Religious Tradition & Church Attendance & Low Knowledge & High Knowledge \\
\hline \hline \multirow{4}{*}{ Not Evangelical } & Less Than 1/week & $0 / 24$ & \\
& At Least 1/week & $2 / 24$ & $17 / 24$ \\
& Proportion Significant & 0.042 & $8 / 24$ \\
& & & 0.521 \\
Evangelical & Less Than 1/week & $1 / 24$ & $11 / 24$ \\
& At Least 1/week & $4 / 24$ & $23 / 24$ \\
& Proportion Significant & 0.104 & 0.708 \\
\hline
\end{tabular}

Table 2: Number of Statistically Significant Policy-Party Relationships. Cell entries are the number of statistically significant $(p<.05)$ relationships between policy opinion (Ideology, Abortion, Gay Marriage, Vouchers, Feminist Favorability, Gay Favorability) and partisan attitude (Party Identification, Bush Approval, Bush Vote, Bush-Kerry Favorability). The denominator in each cell is the total number of estimated policy-party relationships for the given subgroup of respondents, as defined by religious tradition, level of church attendance, and level of political knowledge. 
(a) Party Identification

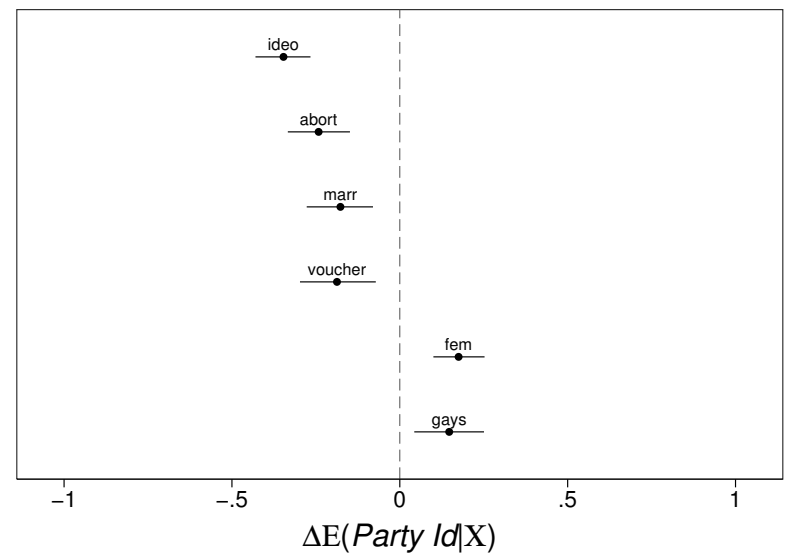

(c) Bush Job Approval

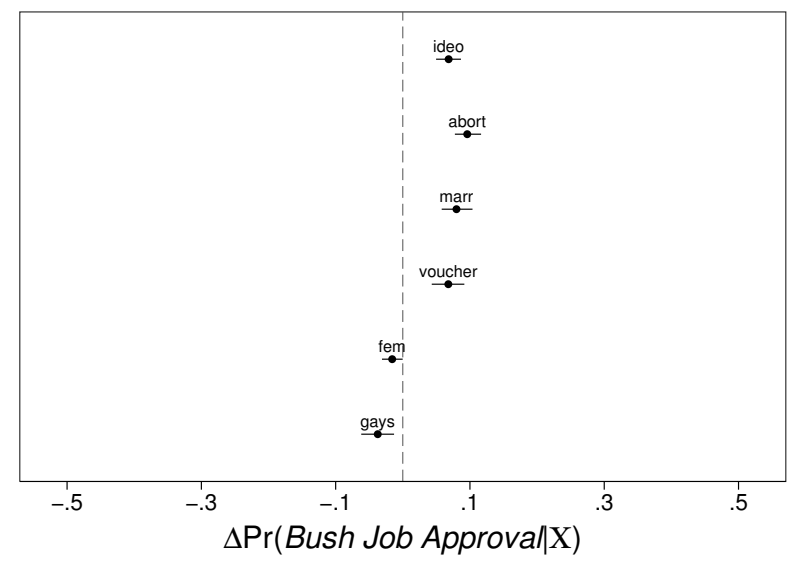

(b) Bush Favorability

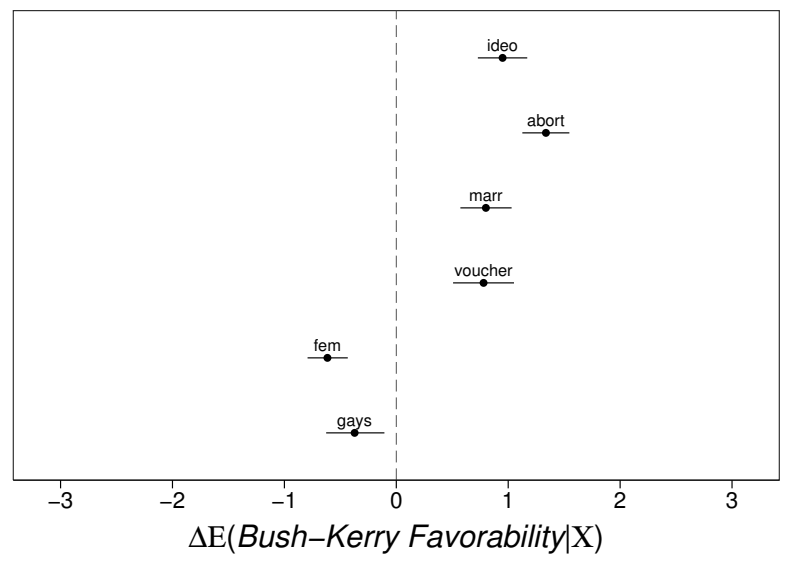

(d) Bush Vote

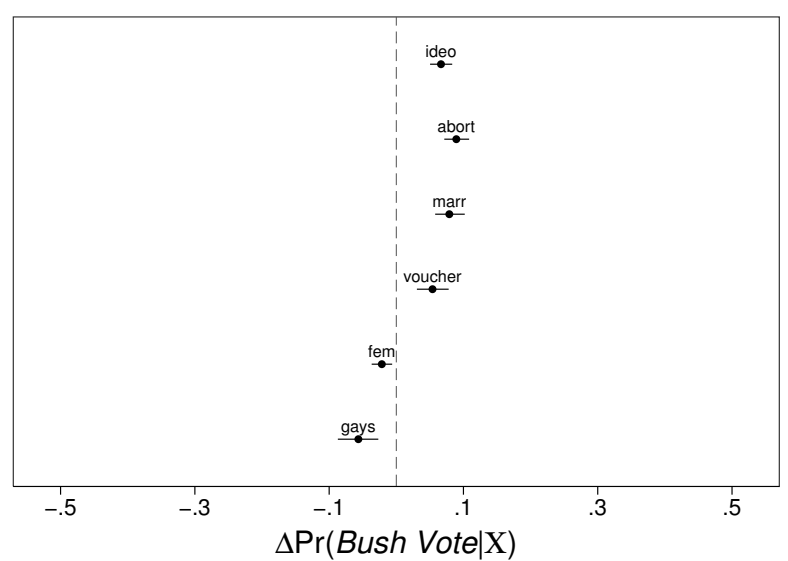

Figure 1: Social Issue Positions and Partisan Attitudes: Estimated Differences: Graph (a) presents the first difference estimates for party identification associated with the 25th versus the 75th percentile position on ideology (ideo), abortion (abort), gay marriage (marr), school vouchers (voucher), and the favorability of feminists (fem) and gay and lesbian groups (gays). Graphs (b), (c), and (d) present these estimates for Bush relative favorability, job approval and vote intention. All estimates are calculated with demographic covariates and interview date held constant at mean values. The $95 \%$ confidence intervals are also displayed. Black respondents only 


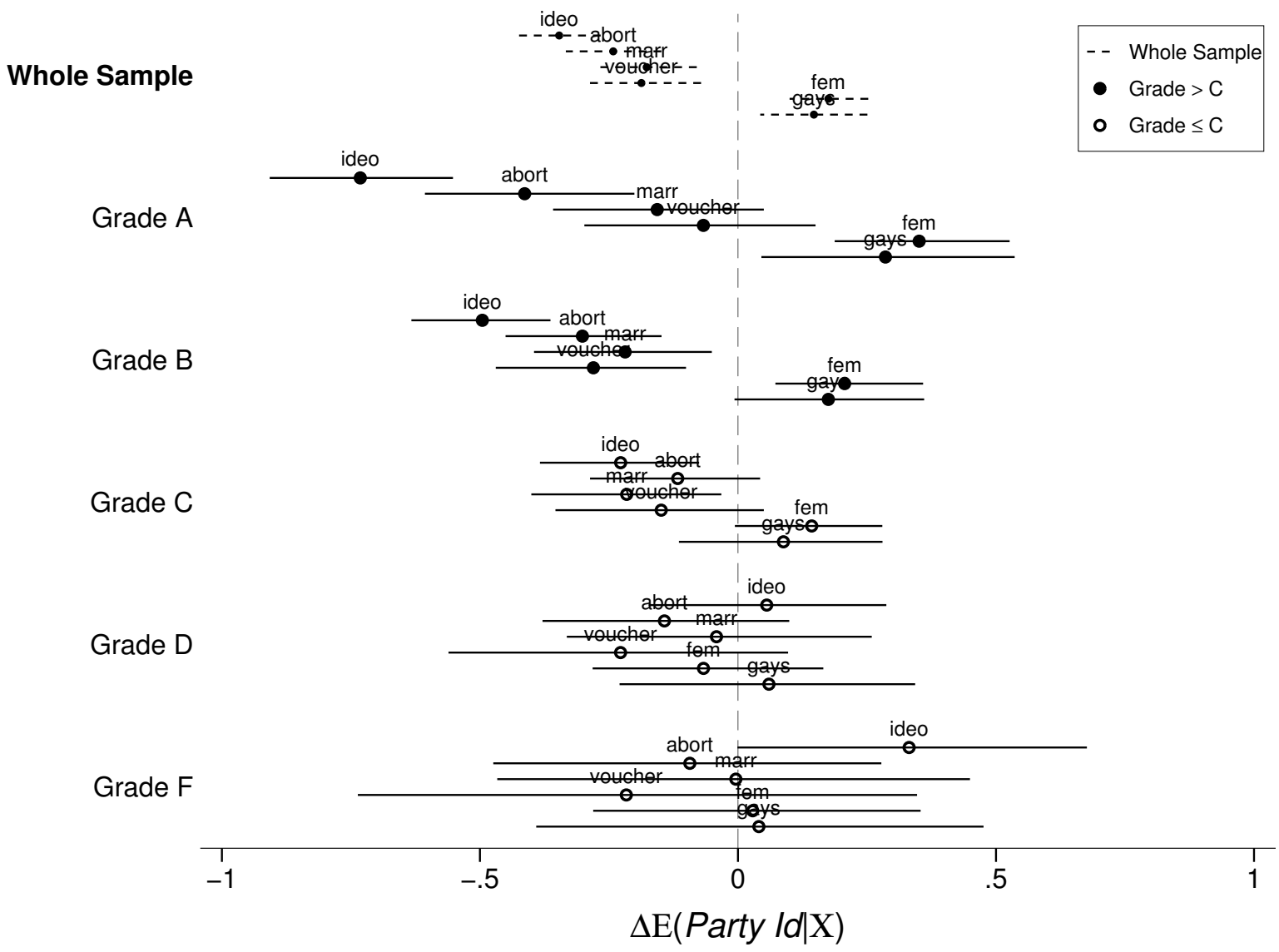

Figure 2: Social Issue Positions and Party Identification, by Political Knowledge: Estimated Differences: Graph presents the first difference estimates for party identification associated with the 25th versus the 75th percentile position on ideology (ideo), abortion (abort), gay marriage (marr), school vouchers (voucher), and the favorability of feminists (fem) and gay and lesbian groups (gays). The estimates are conditional on the level of political knowledge (Grade A thru F), and are calculated with demographic covariates and interview date held constant at mean values. The $95 \%$ confidence intervals are also displayed. Black respondents only 


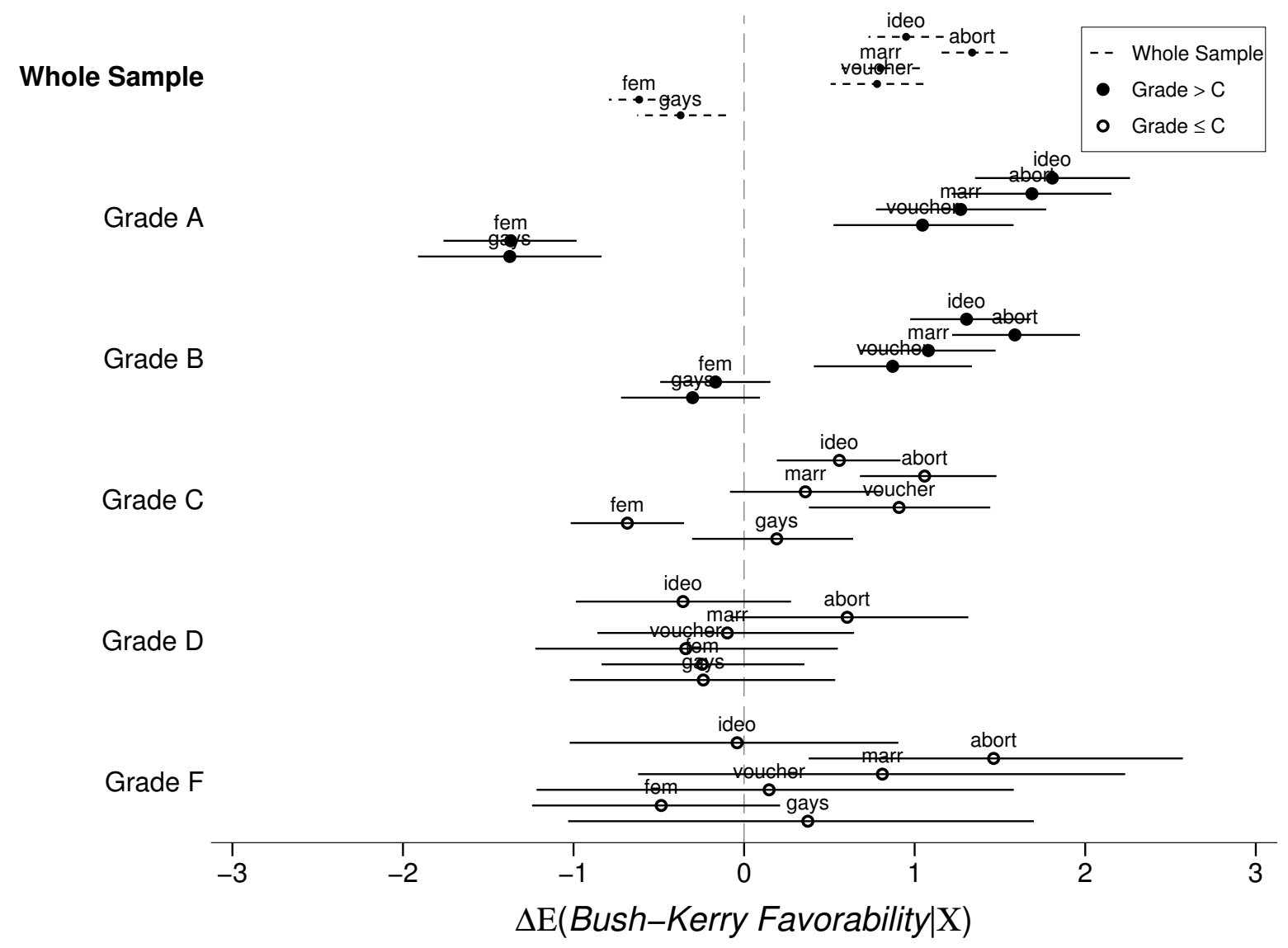

Figure 3: Social Issue Positions and Bush Favorability, by Political Knowledge: Estimated Differences: Graph presents the first difference estimates for Bush relative favorability associated with the 25th versus the 75th percentile position on ideology (ideo), abortion (abort), gay marriage (marr), school vouchers (voucher), and the favorability of feminists (fem) and gay and lesbian groups (gays). The estimates are conditional on the level of political knowledge (Grade A thru F), and are calculated with demographic covariates and interview date held constant at mean values. The $95 \%$ confidence intervals are also displayed. Black respondents only 


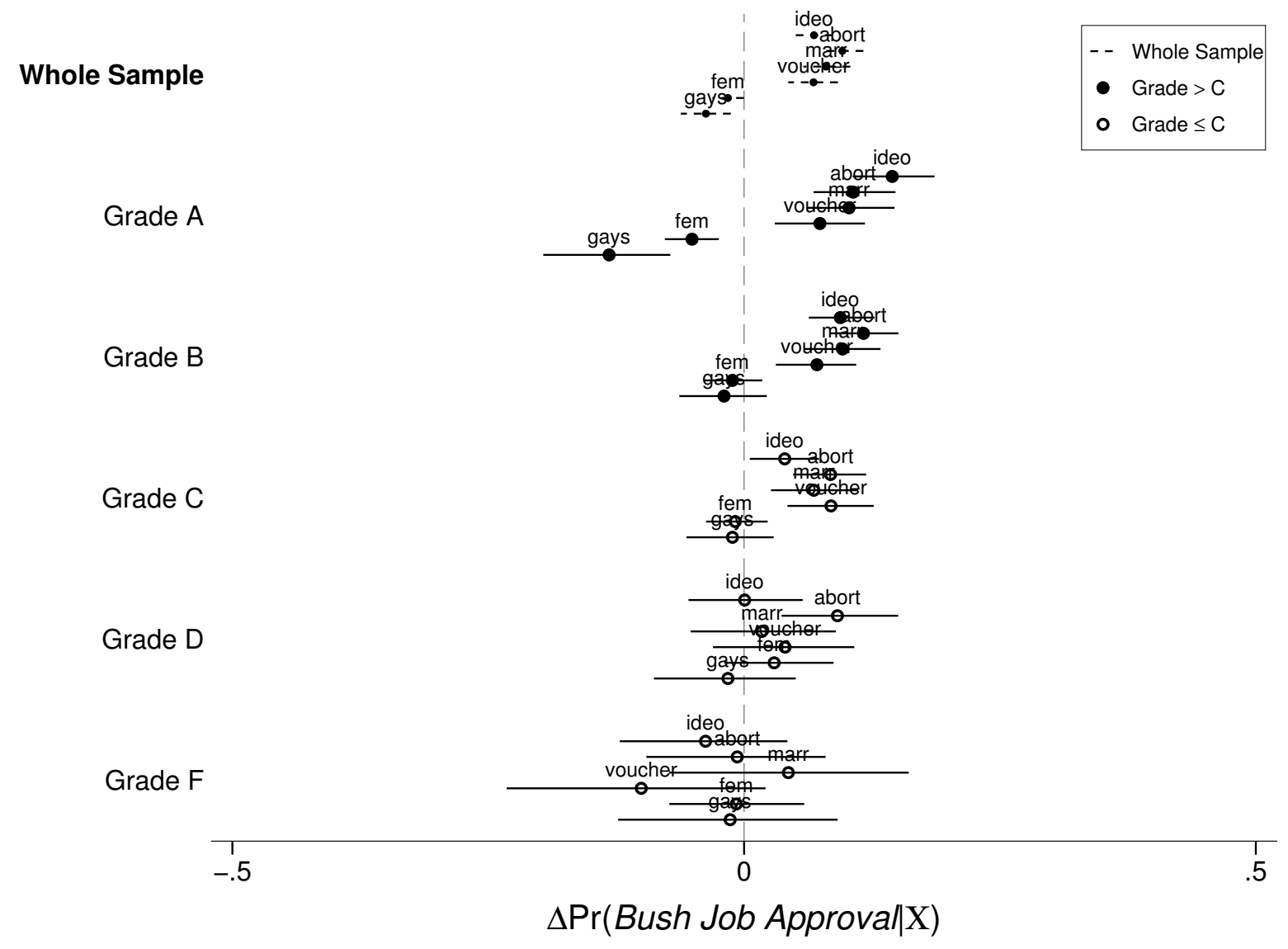

Figure 4: Social Issue Positions and Bush Job Approval, by Political Knowledge: Estimated Differences: Graph presents the first difference estimates for the probability of Bush job approval associated with the 25 th versus the 75 th percentile position on ideology (ideo), abortion (abort), gay marriage (marr), school vouchers (voucher), and the favorability of feminists (fem) and gay and lesbian groups (gays). The estimates are conditional on the level of political knowledge (Grade A thru F), and are calculated with demographic covariates and interview date held constant at mean values. The $95 \%$ confidence intervals are also displayed. Black respondents only. 
Whole Sample

Grade A

Grade B

Grade C

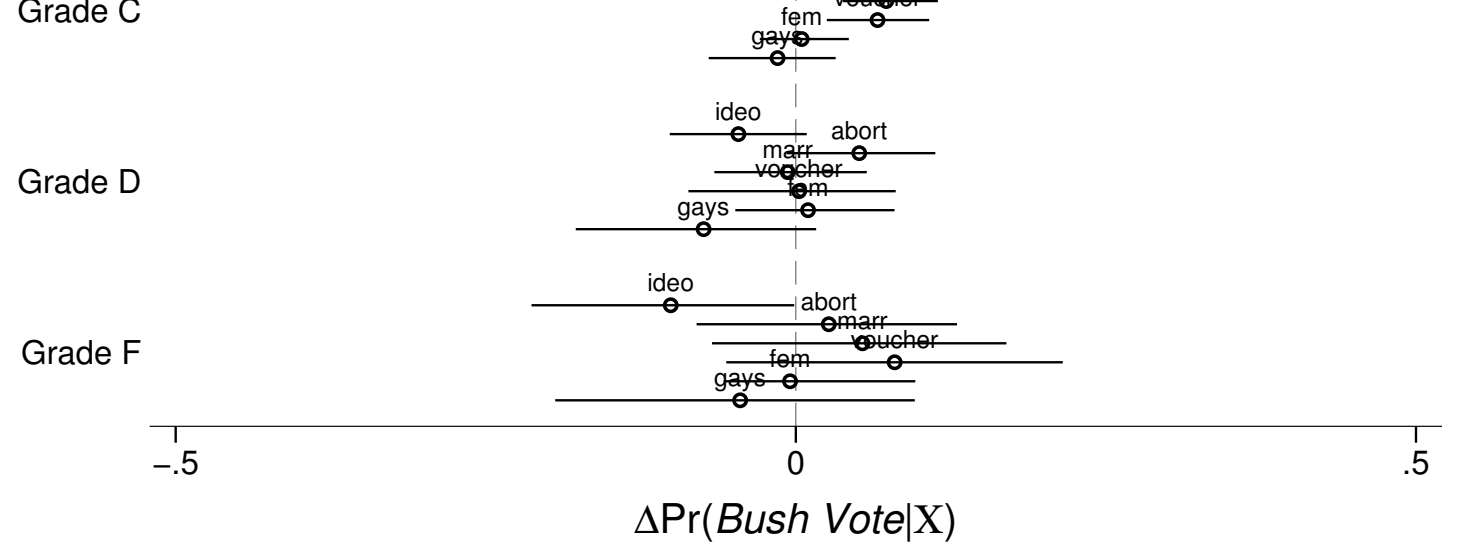

- - Whole Sample

- Grade $>$ C

- Grade $\leq \mathrm{C}$

Figure 5: Social Issue Positions and Bush Vote, by Political Knowledge: Estimated Differences: Graph presents the first difference estimates for the probability of voting for Bush associated with the 25 th versus the 75 th percentile position on ideology (ideo), abortion (abort), gay marriage (marr), school vouchers (voucher), and the favorability of feminists (fem) and gay and lesbian groups (gays). The estimates are conditional on the level of political knowledge (Grade A thru F), and are calculated with demographic covariates and interview date held constant at mean values. The $95 \%$ confidence intervals are also displayed. Black respondents only 


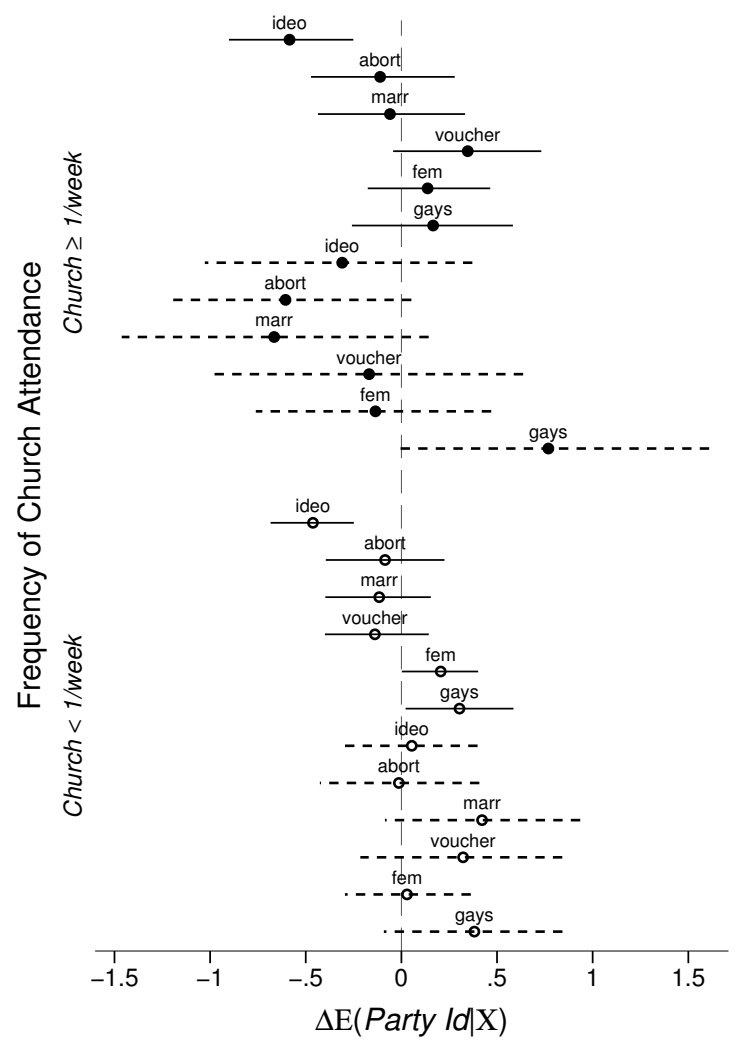

Born-Again and Evangelicals Excluded

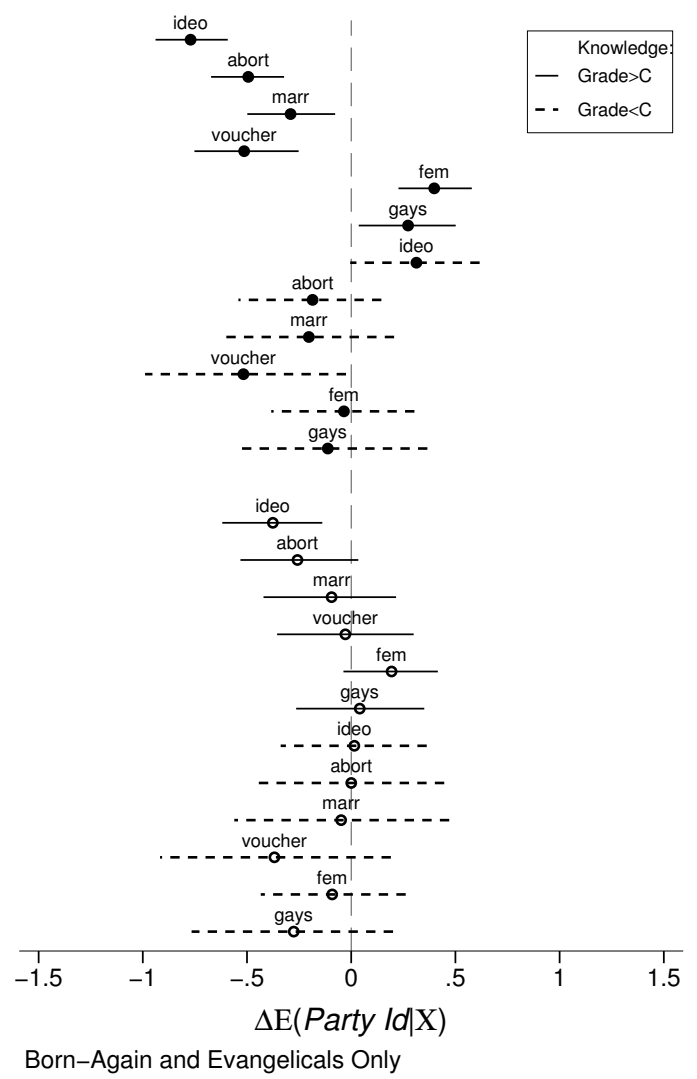

Born-Again and Evangelicals Only

Figure 6: Social Issue Positions and Party Identification, by Issue Salience and Political Knowledge: Estimated Differences: Graph presents the first difference estimates for party identification associated with the 25th versus the 75th percentile position on ideology (ideo), abortion (abort), gay marriage (marr), school vouchers (voucher), and the favorability of feminists (fem) and gay and lesbian groups (gays). The estimates are conditional on religious tradition (NonEvangelical, Evangelical), the frequency of church attendance (at least once per week, less than once per week) and the level of political knowledge (better than Grade C, Grade C or less), and are calculated with demographic covariates and interview date held constant at mean values. The $95 \%$ confidence intervals are also displayed. Black respondents only 


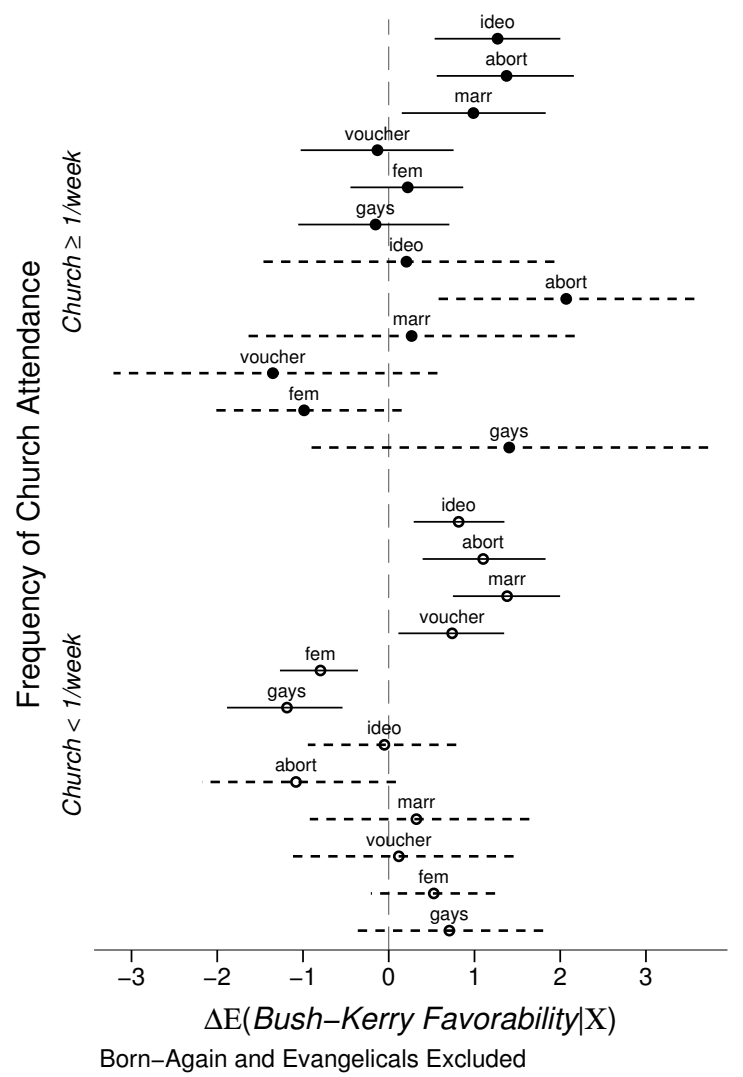

Born-Again and Evangelicals Excluded

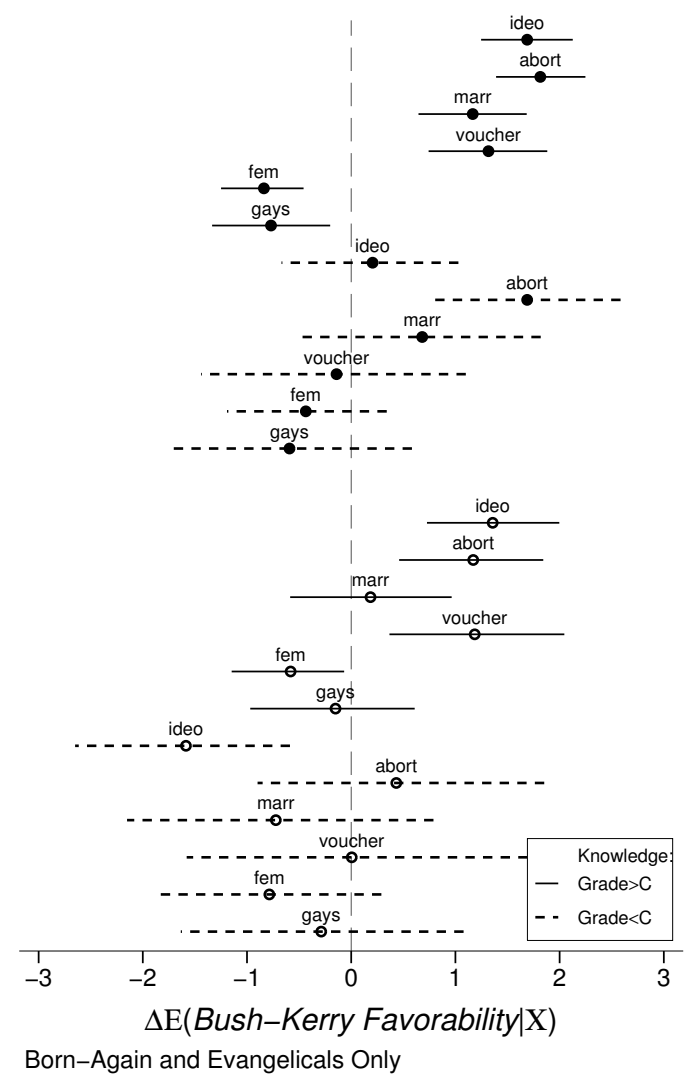

Figure 7: Social Issue Positions and Bush Favorability, by Issue Salience and Political Knowledge: Estimated Differences: Graph presents the first difference estimates for Bush relative favorability associated with the 25 th versus the 75 th percentile position on ideology (ideo), abortion (abort), gay marriage (marr), school vouchers (voucher), and the favorability of feminists (fem) and gay and lesbian groups (gays). The estimates are conditional on religious tradition (NonEvangelical, Evangelical), the frequency of church attendance (at least once per week, less than once per week) and the level of political knowledge (better than Grade C, Grade C or less), and are calculated with demographic covariates and interview date held constant at mean values. The $95 \%$ confidence intervals are also displayed. Black respondents only 

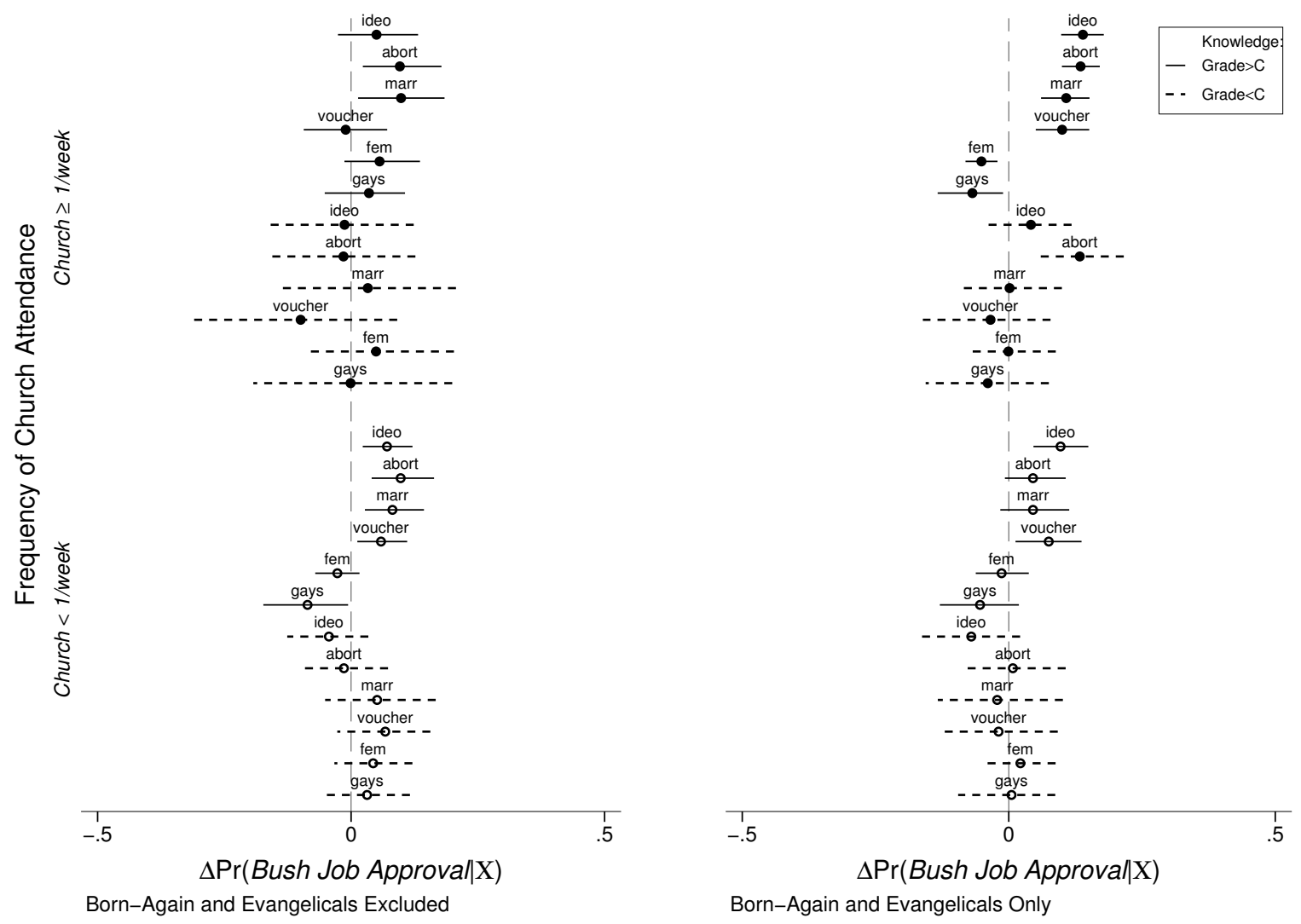

Figure 8: Social Issue Positions and Bush Job Approval, by Issue Salience and Political Knowledge: Estimated Differences: Graph presents the first difference estimates for the probability of Bush job approval associated with the 25th versus the 75th percentile position on ideology (ideo), abortion (abort), gay marriage (marr), school vouchers (voucher), and the favorability of feminists (fem) and gay and lesbian groups (gays). The estimates are conditional on religious tradition (Non-Evangelical, Evangelical), the frequency of church attendance (at least once per week, less than once per week) and the level of political knowledge (better than Grade C, Grade C or less), and are calculated with demographic covariates and interview date held constant at mean values. The $95 \%$ confidence intervals are also displayed. Black respondents only 

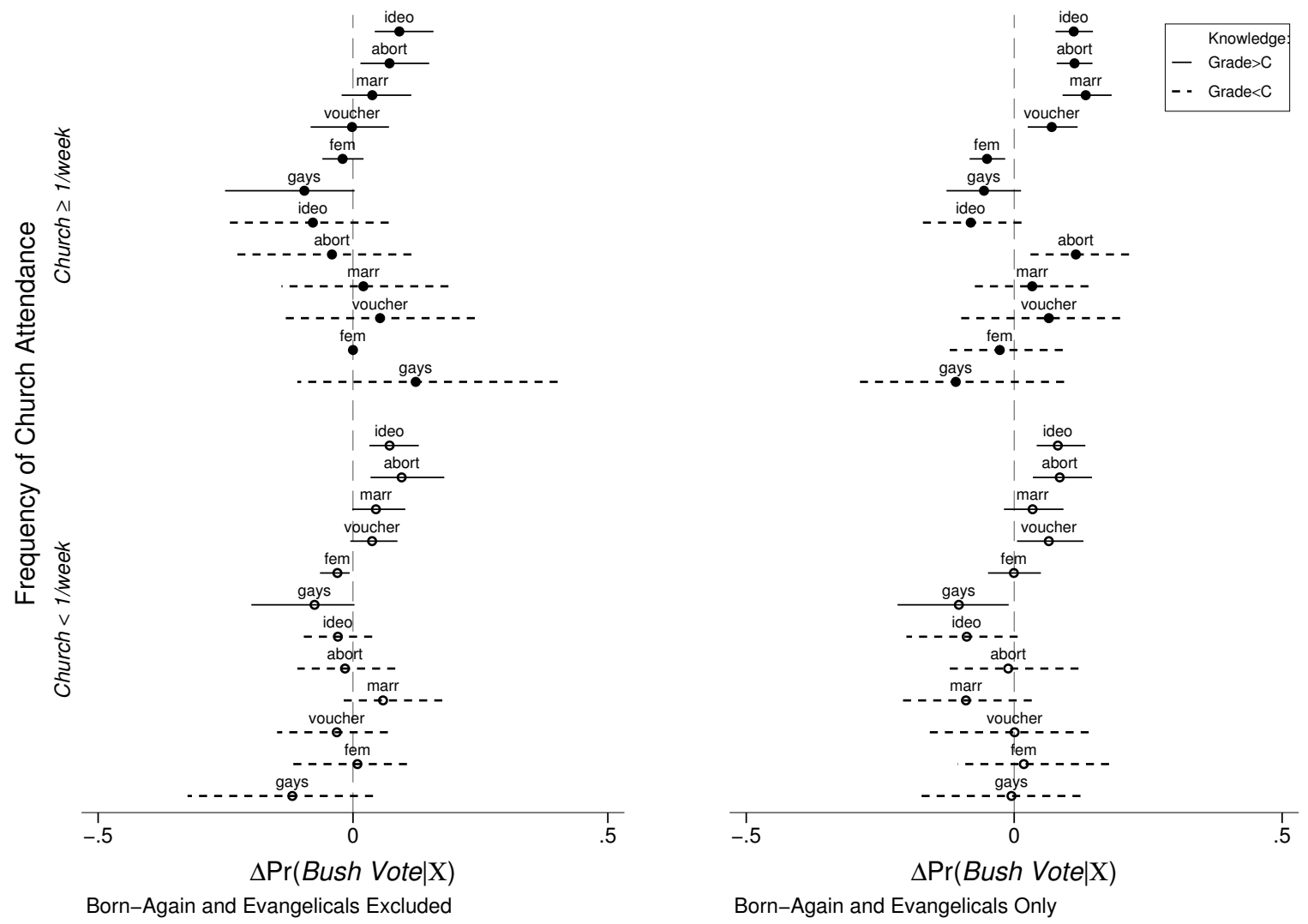

Figure 9: Social Issue Positions and Bush Vote, by Issue Salience and Political Knowledge: Estimated Differences: Graph presents the first difference estimates for the probability of voting for Bush associated with the 25 th versus the 75 th percentile position on ideology (ideo), abortion (abort), gay marriage (marr), school vouchers (voucher), and the favorability of feminists (fem) and gay and lesbian groups (gays). The estimates are conditional on religious tradition (Non-Evangelical, Evangelical), the frequency of church attendance (at least once per week, less than once per week) and the level of political knowledge (better than Grade C, Grade C or less), and are calculated with demographic covariates and interview date held constant at mean values. The $95 \%$ confidence intervals are also displayed. Black respondents only 
(a) Party Identification

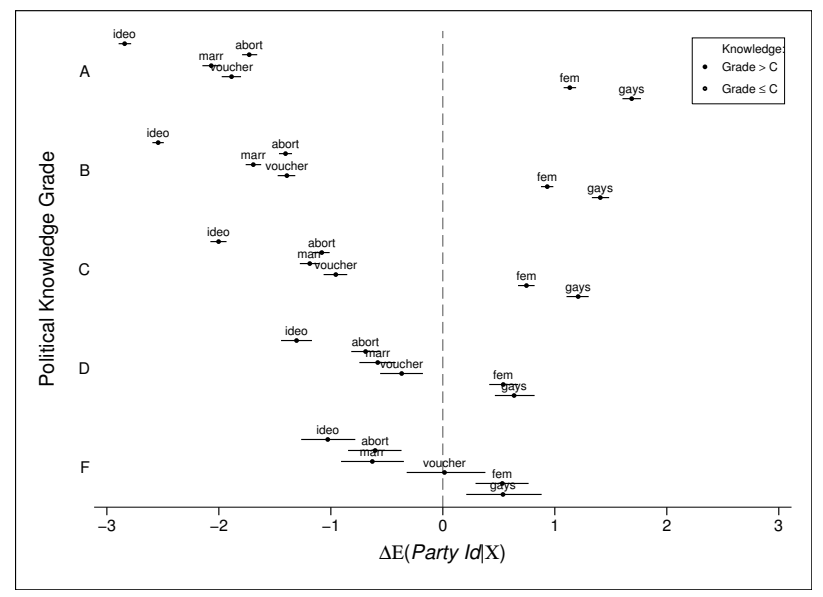

(c) Bush Job Approval

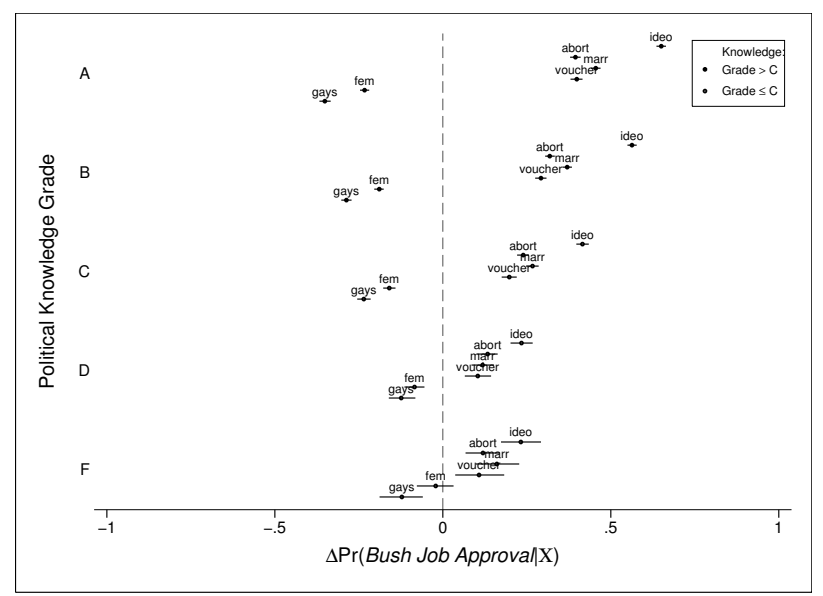

(b) Bush Favorability

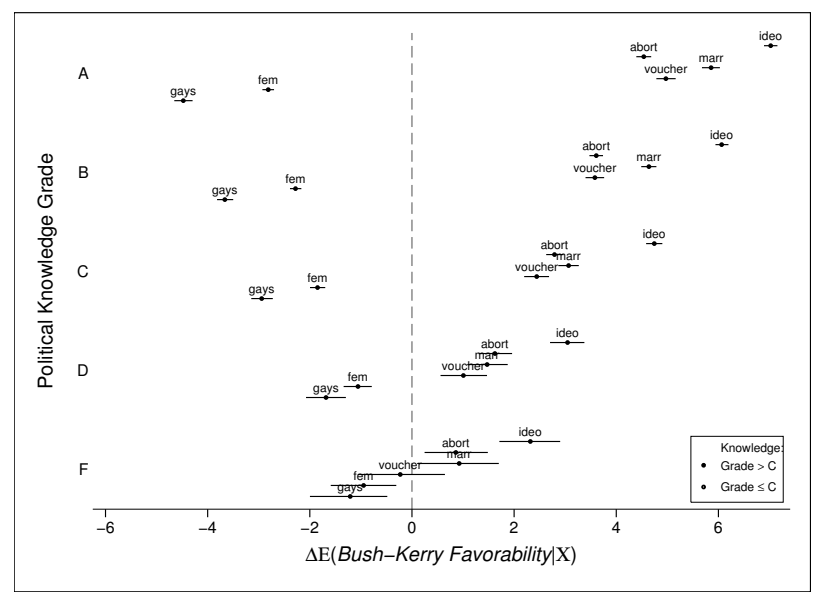

(d) Bush Vote

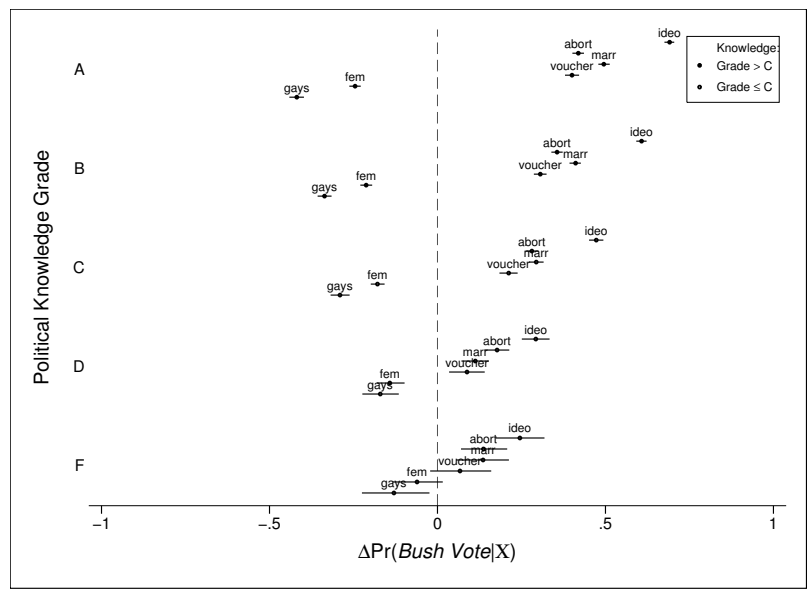

Figure 10: Social Issue Positions and Partisan Attitudes, by Political Knowledge: Estimated Differences: Graph (a) presents the first difference estimates for party identification associated with the 25 th versus the 75 th percentile Black position on ideology (ideo), abortion (abort), gay marriage (marr), school vouchers (voucher), and the favorability of feminists (fem) and gay and lesbian groups (gays). Graphs (b), (c), and (d) present these estimates for Bush relative favorability, job approval and vote intention. The estimates are conditional on the level of political knowledge (Grade A thru F), and are calculated with demographic covariates and interview date held constant at mean values. The $95 \%$ confidence intervals are also displayed. White respondents only 